\title{
Implementation of Lean in Four-Wheel Drive Front Axle Sub Assy line
}

\author{
T. Premkumar, K. Shanmugam, V. Kandeeban
}

Abstract: This project deals with the Optimizing the process and eliminating the waste in Four Wheel Drive front axle sub assembly line. Four wheel drive sub assembly line consist of 20 different sub-assemblies are available. In which Axle housing sub assy takes more time to complete i.e. around 20.8 min which is more than TAKT time. In this most fatigue operation is Bush pressing which is done by manual hammering. Due to the manual hammering process TAKT time increases and improper bush assy into the axle housing which leads to failure in the front axle function which results in warranty claims thus increasing the external cost to the company. As the existing process is manual, the accuracy of the pressing operation is not to the standards, while pressing the bush, there is no assurance of full placement of the bush in the axle, also the fatigue is more, and there may be chances of lack of skill in the work. The interference tonnage is found to be 3 to 4 tonnes and so the intensifier unit for the appropriate pressure is to be designed initially $100 \%$ inspection is done after bush pressing to check correct position of bush assy, internal diameter of the bush using gauges, Further through PFMEA critical process are identified for failure.

Keywords: SMED - Lean, SMED, PFMEA.

\section{INTRODUCTION}

L ean manufacturing was developed for maximum utilization of the resource and reducing the waste [1] Lean manufacturing widely used in the industry to increase the productivity without additional resource [2] Due to fast change in the market industry is forced to face the challenges to produce low volume high variant products [3] To implement the lean in assy line need to do activities like analyzing the layout, batch size and process follow to increase overall equipment effectiveness [4] Designing facility in order to flexible, modularity and scalable responsive to manufacturing system to accommodate dynamic changes of product variant [5] lean manufacturing principles involves reducing the cost by identifying the value added and non-value added activity [6] Lean manufacturing is used to fill the current gap in proper innovative approach to measure the lean performance manufacturing system [7] Lean manufacturing is used to demonstrate positive effect approach to increase efficiency when crises occurred.[8] Lean as a long

Revised Manuscript Received on December 15, 2019.

* Correspondence Author

T. Premkumar *, department of Mechanical Engineering, Kalasalingam Academy of Research \& Education, Virudhunagar Dist., Tamilnadu, India. Email: t.premkumar@klu.ac.in

K. Shanmugam , department of Mechanical Engineering, Kalasalingam Academy of Research \& Education, Virudhunagar Dist., Tamilnadu, India. Email: kshaann@gmail.com

V. Kandeeban, department of Quality Assurance, Tractor and Farm Equipment (TAFE) Ltd., Kalladipatti - 624201, Dindigul Dist, Tamilnadu, India. Email: Kandeebanv@tafe.com term philosophy about the right process which is used produce a right product by adding value to the organization [9] value stream mapping is the main tool is used to identify the opportunities for the various lean techniques, which used discrete manufacturing rather than the continuous manufacturing [10] Elimination non value added activities and increasing the value added activities which directly increases the plant performance.

\section{A. Four wheel drive tractor}

Tractors can be generally classified by number of axles or wheels, with main categories of two-wheel drive and four wheel drive tractors. Among four-wheel tractors most are two-wheel drive (usually at the rear); but many are two wheel drive with front wheel assist, four-wheel drive (often with articulated steering), or track tractors (with steel or rubber tracks).

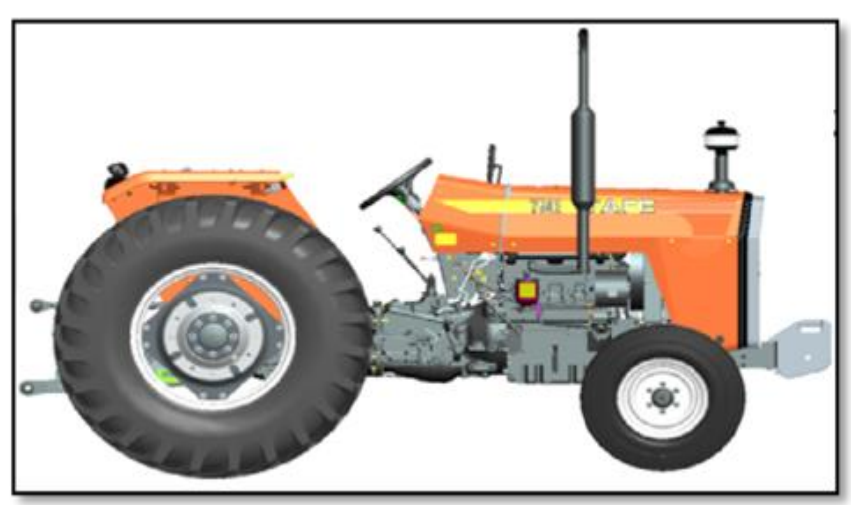

Fig. 1. Photographic view of the Tractor

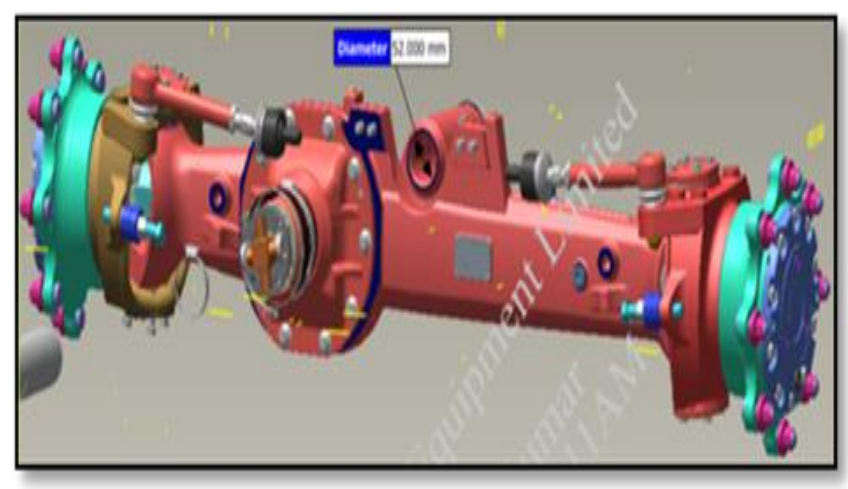

Fig. 2. Schematic diagram of of Four wheel drive front axle 


\section{Implementation of Lean in Four-Wheel Drive Front Axle Sub Assy line}

Four-wheel drive (4WD) refers to vehicles with two axles providing torque to four axle ends. The term "4WD" is typically designated for vehicles equipped with a transfer case which switches between 2WD and 4WD operating modes, either manually or automatically.

\section{B. Over view of farm equipment four wheel drive axle}

The tractor chassis consists of Rear Transmission, Gear box, Engine and four wheel drive front axle. This figure shows the over view of chassis assembly layout.

When the Tractor key is on the Power is transmitted to the Gear box from the Engine, then it is transmitted to Rear Transmission, While Engaging the 4WD lever, the Power is transmitted to 4WD Front axle through POD assembly via propeller shaft assembly.

\section{Chassis assembly layout}

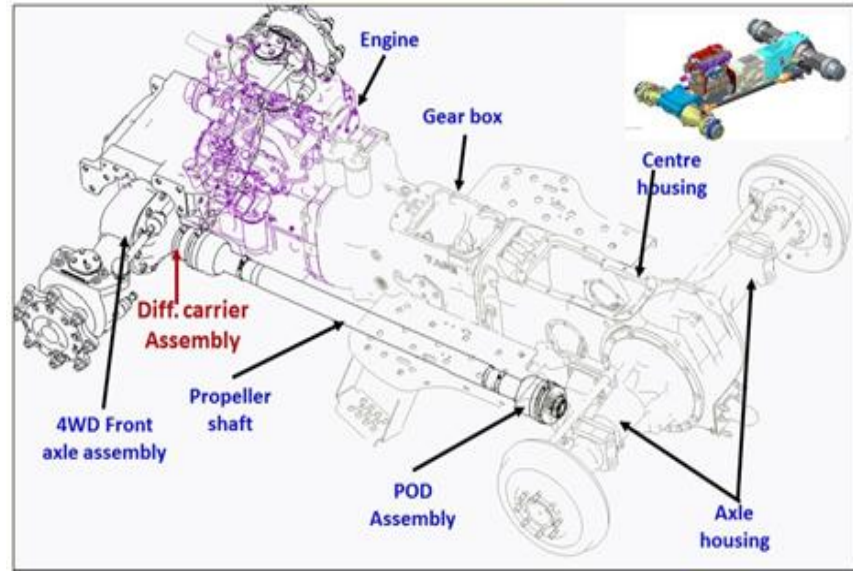

Fig. 3. Chassis assy layout with front axle \& rear axle assy

\section{PROBLEM DEFINITION}

In 4WD front axle assembly line Center bush is assembled on 4WD front axle manually by using hammer, To make complete pressing of Bush inside the front Axle, 2 Ton load required, to achieve the same operator do hammering operation. Also to press the bush to the required position operator needs to do 15 to 18 Strokes by hammer i.e., it depends upon on the operator and also the accuracy of the pressing operation will not be uniform throughout the assembly. Due to manual operation, there is possibility for bush chipping off, improper pressing.it causes rework and scrap in front axle assembly will be high. So Manual pressing of bush in front Axle leads to operator more fatigue, Damage in bush, Detraction in quality.

Manual operation in Front axle sub assembly:

1. Middle bush pressing in Axle housing

2. Clamping of axle housing with fixture

3. Two man power used for steering arm assy

4. Takt time is higher

5. Operator fatigue is more

Objective:

1. $100 \%$ elimination of manual assembly in Four wheel drive front axle sub assy
2. To reduce the Takt time

3. To improve the internal customer satisfaction

4. To Improve Right First Time

5. To reduce the operator fatigue

\section{METHODOLOGY}

Six Sigma is a structured, measurable method used for the purpose of identifying root causes of problems up front to prevent waste of time, resources, or insufficient project quality from occurring throughout the project. The five phases (DMEDI) for managing projects include:

Define the project purpose, establish goals, structure and identify the value for the customer and company.

Measure throughout the process and project completion by determining how you will quantify success.

Explore new ways to accomplish completion of the project to continually improve the process.

Develop a comprehensive plan, including personnel and financial resource needs to organize and implement the project as identified in the defined phase.

Implement the project for completion.

\section{A. Define}

Four wheel drive sub assembly line consist of 20 different sub-assemblies are available. To do complete one number of Four -Wheel drive front axle takes TAKT TIME of 19.64 min. Among this 20 Sub-assemblies one sub assembly i.e Axle housing sub assembly takes $20.8 \mathrm{~min}$ which is more than the TAKT TIME of $19.64 \mathrm{~min}$. Because Axle housing sub assembly consist of following activity which causes to increase TAKT TIME.

1. Axle Housing Bush pressing at Middle for pivot pin assembly - Manual operation

2. Manual clamp to hold the front axle with fixture- 3 clamps are used - Manual operation

3. Assembly of steering arm with cylinder which requires to arm power to hold the steering arm Manual operation

Challenge here is Model mix is more, there four different 4WD Front axles are assembled as follows

\section{G 4.1/G4.2 Front axle - Gear pair change \\ G 5 Front Axle - Longer Axle \\ 50 Hp Front Axle - - Swivel housing Change \\ 2G1 Front Axle - Shorter Axle}

So Facility to be designed to accommodate all the models in single base machine, and for 
pressing \& clamping its proposed that Hydraulic or hydro pneumatic set up to be provided.

Takt is $19.64 \mathrm{sec}$ for four wheel drive front axle sub assy line but Axle housing assy takes 20.8 min to complete one assy.

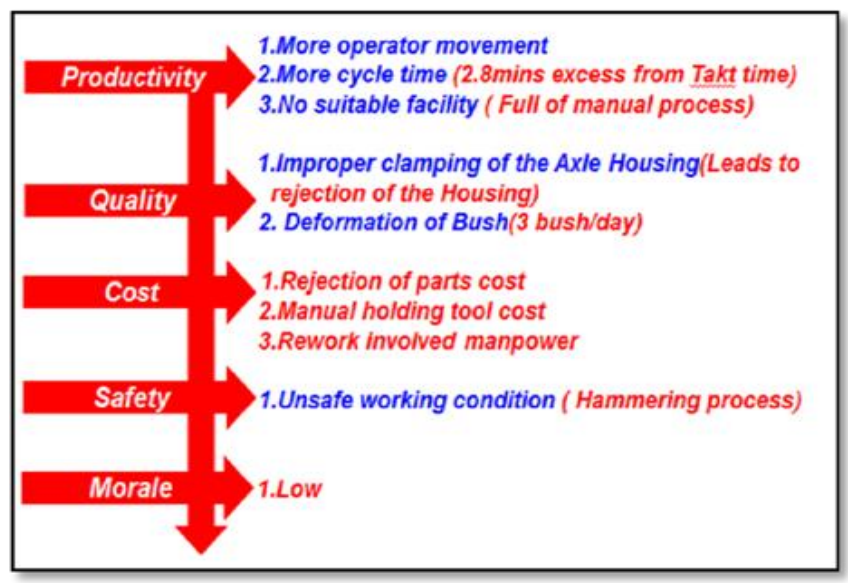

Fig. 4. Impact on Productivity, Quality, cost and safety.

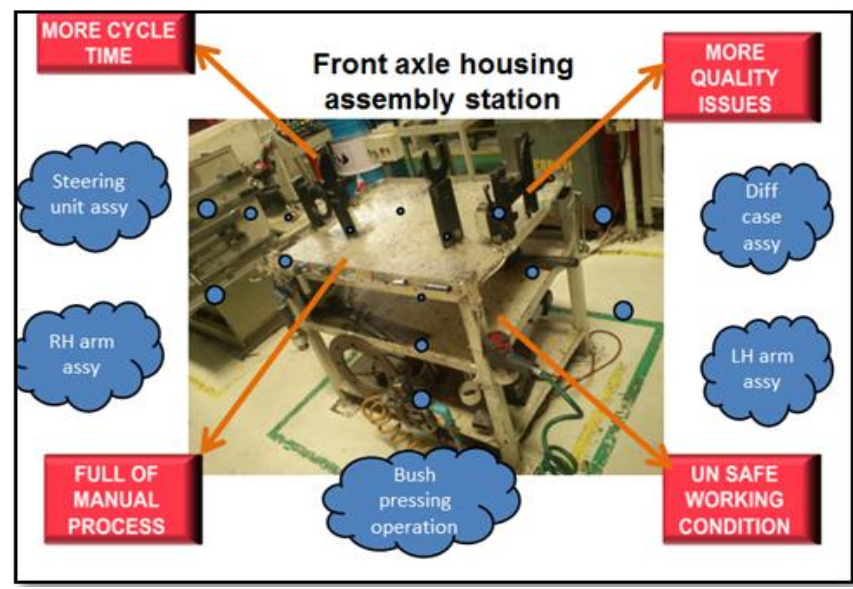

Fig. 5. Current assy facility to assemble four wheel drive axle.

TAKT Time for the four wheel drive front axle is 19.64 min, for Axle housing Sub assy stage TAKT time $20.8 \mathrm{~min}$. This is above the TAKT time due to that productivity reduced.

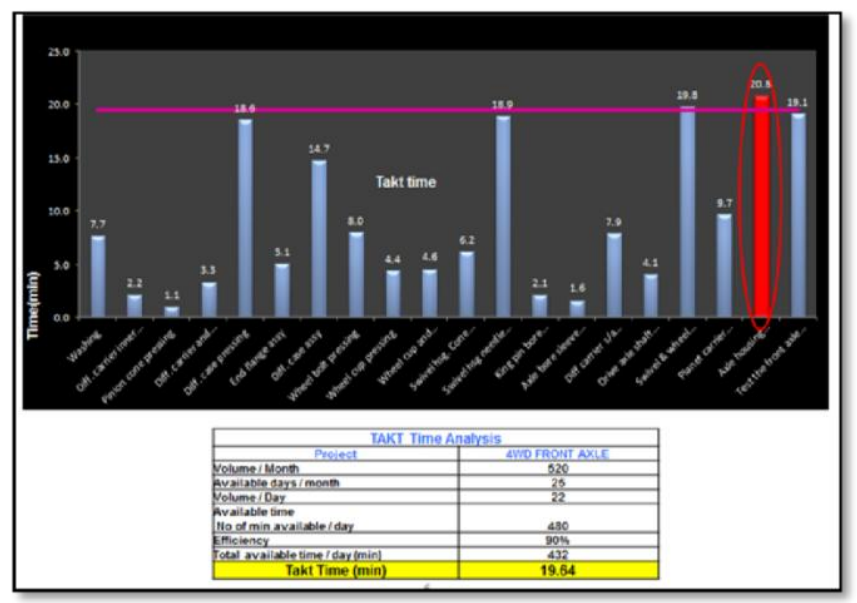

Fig. 6. Takt time analysis of various sub assy of four wheel drive front axle

\section{B. Measure}

Target

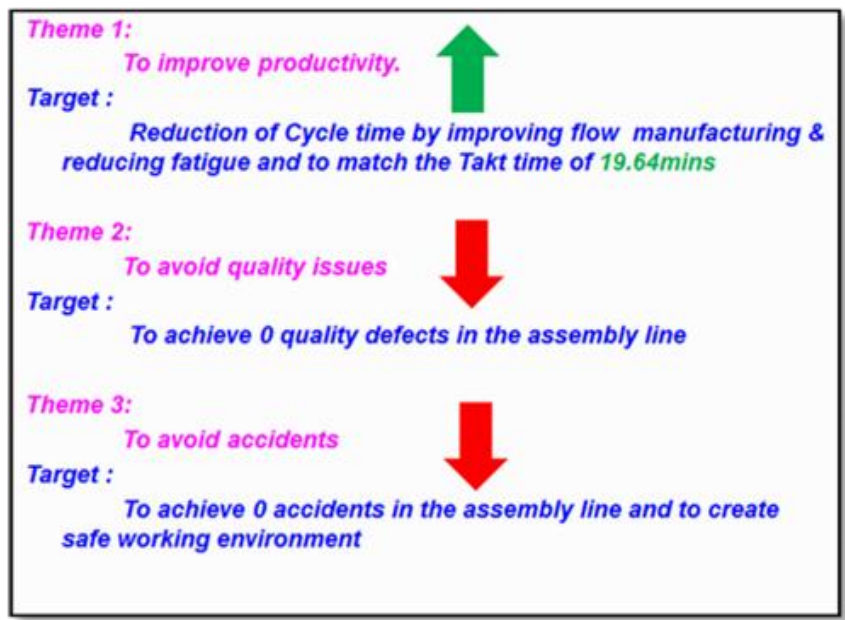

Fig. 7.Target to increase productivity reduce quality issue

Time Study - for bush pressing currently 130 secs

Table- I: Cycle tme analysis in axle hoising bush pressing

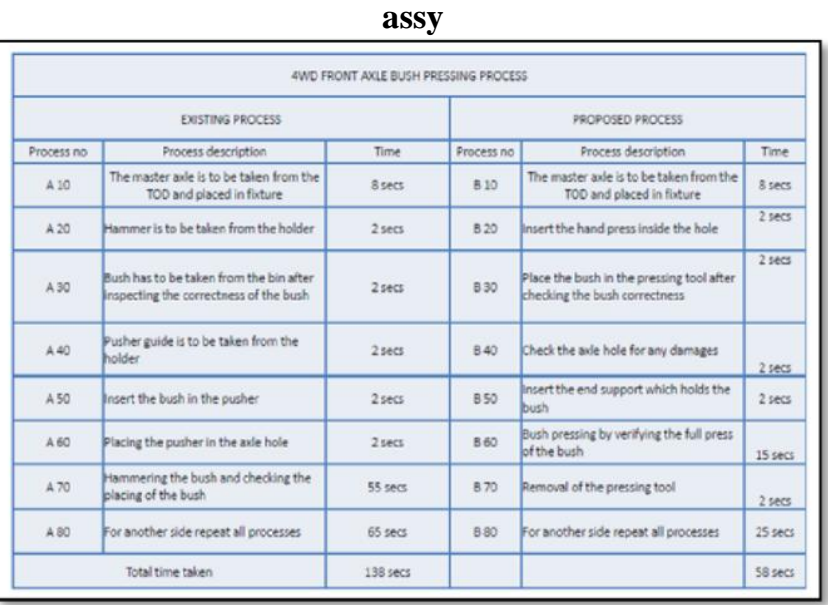

\section{Explore}

Concept Design has made for the front axle bush pressing, component clamping and steering arm tightening.

In this hydraulic power pack is used and for bush pressing hollow cylinder is used. Tonnage capacity is 4 Ton.

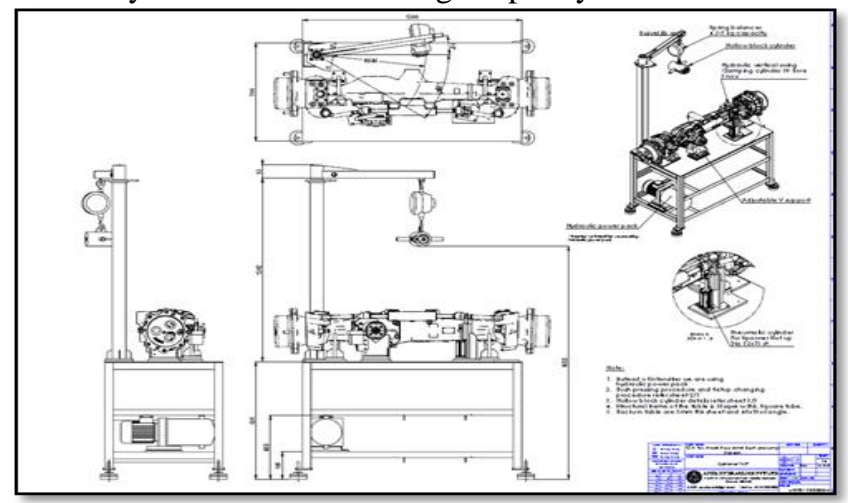

Fig. 8. Concept Design of new sub assy fixture with toe in checking 


\section{Implementation of Lean in Four-Wheel Drive Front Axle Sub Assy line}

\section{DAP Observation}

Based on the Concept design some of the observation shared to the supplier.

1. Auto position change required.

2. Auto adjustment for position change required.

3. Shifting of jib arm to front position for easy accessibility

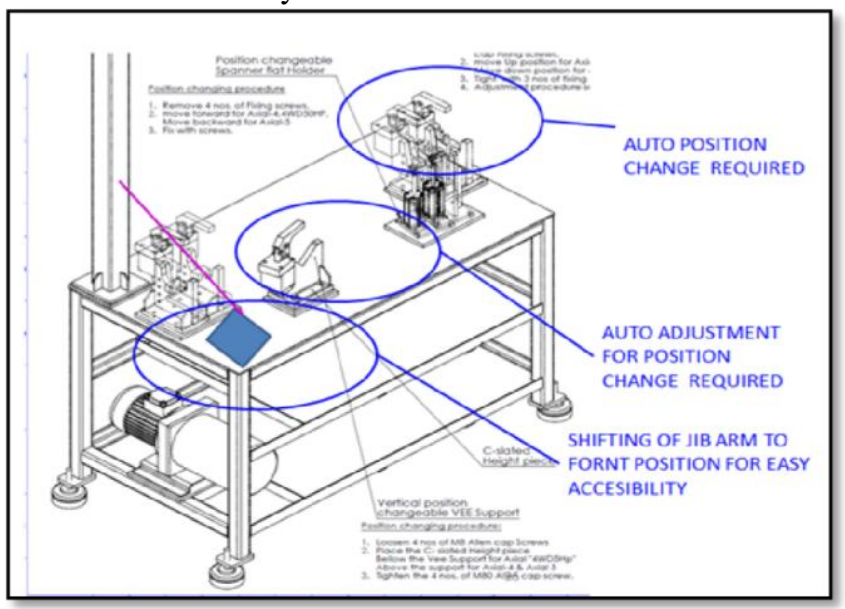

Fig. 9. Feedback based on new design

FEA analysis

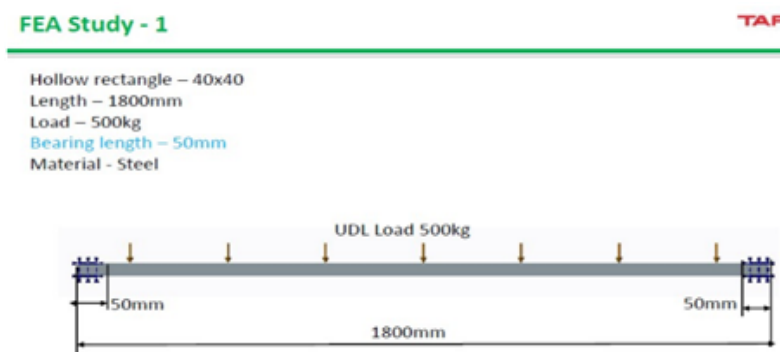

Fig. 10. FEA Study -1

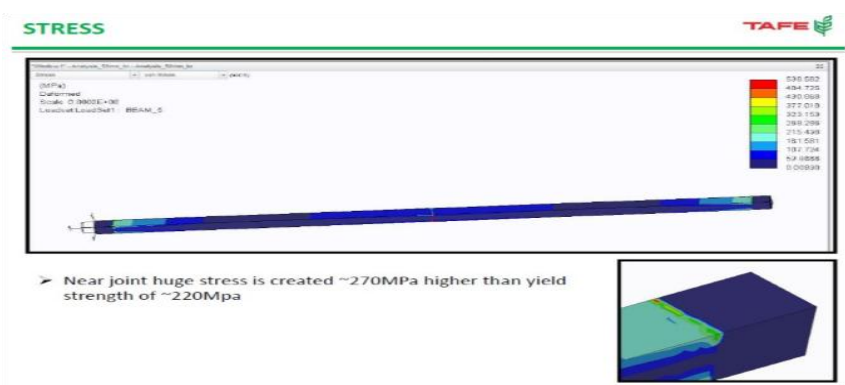

Fig. 11. FEA Study -stress 1

FEA Study - 2

TAFE \&

Hollow rectangle $-40 \times 40$

Length $-1800 \mathrm{~mm}$

Load - 500kg

Bearing length $-100 \mathrm{~mm}$

Material - Steel

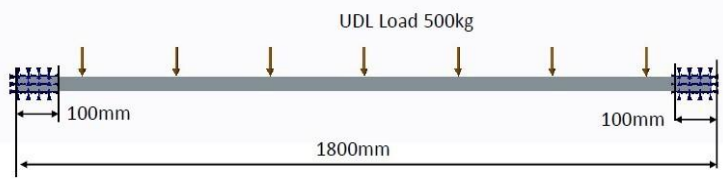

Fig. 12. FEA Study -2

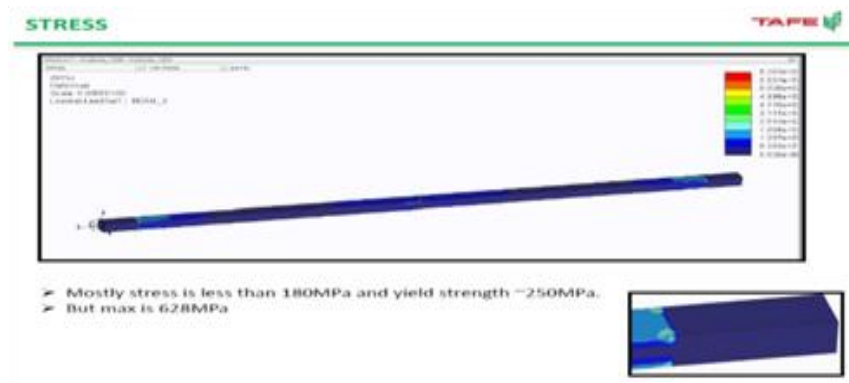

Fig. 13. FEA Study -stress 2

\section{Develop}

At the time of manufacturing the facility at supplier audit will be done against the design to ensure the right first and delivery on time

Many inputs will be given to while manufacturing to change the Sliding movement with automatically to a different position

Commonised facility for 5 different front axle

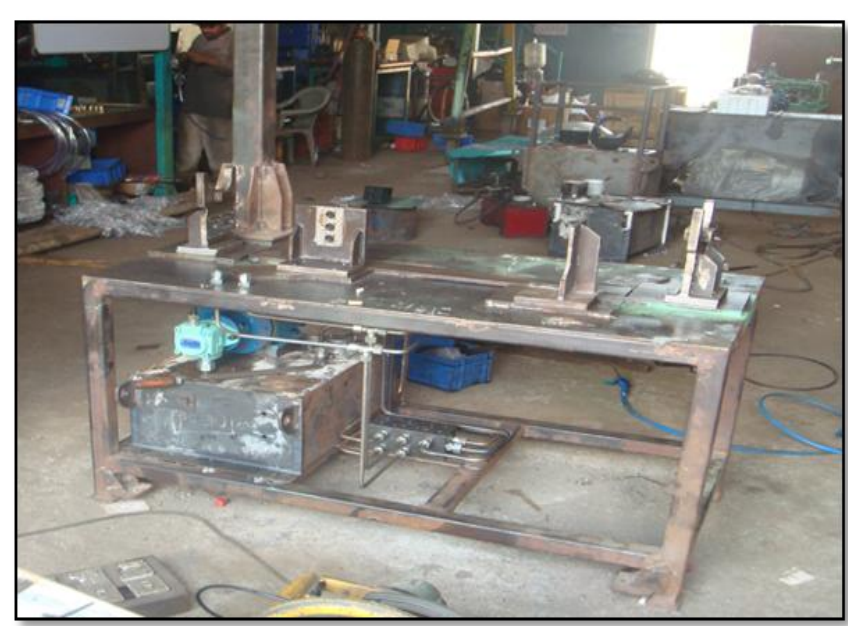

Fig. 14. New facility under manufacturing at supplier end

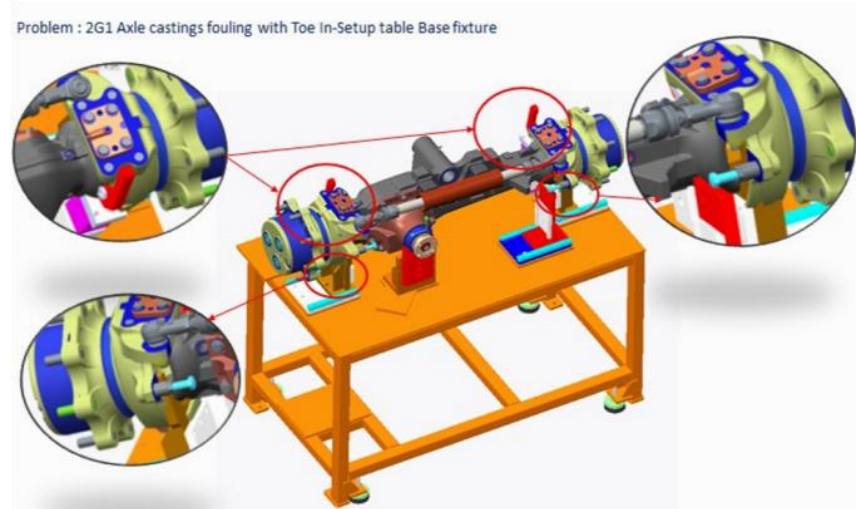

Fig. 15. 3D model commonised facility to accomadate all 5 variants

During manufacturing one more new model called 2G1 front axle introduced which is shorter in length and casting dimensions are different. To accommodate this model also in the previous design slightly design is modified

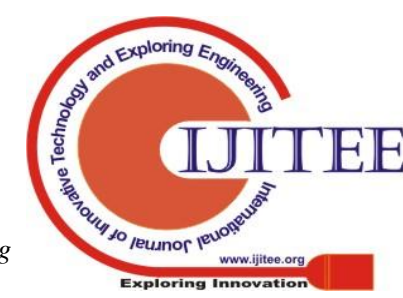


1. Clamping position changed

2. Hydraulic hose orientation changed

3. Jib arm position changed

Now all five different front axles sub assy can be done in the same fixture

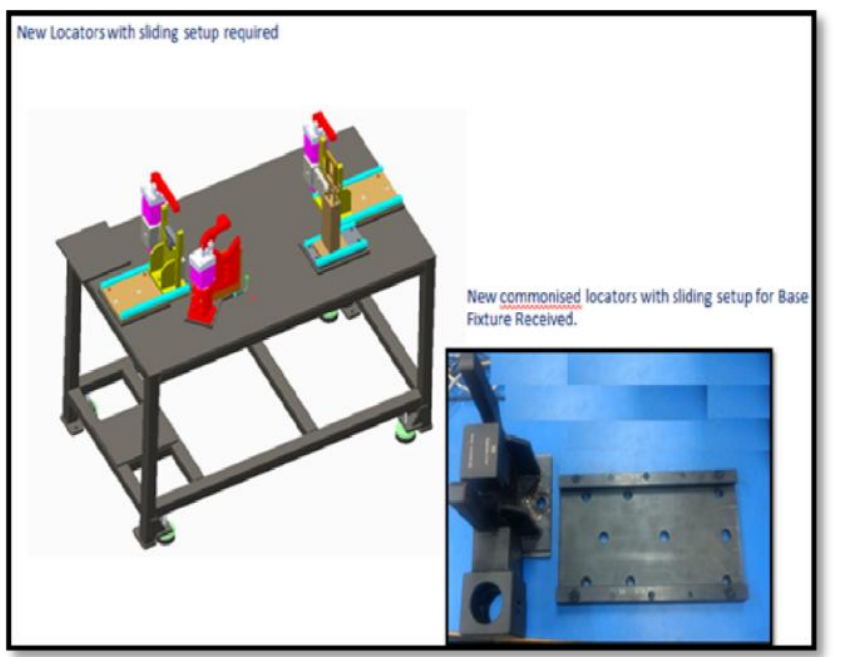

Fig. 16. Add on plate plates for Commonised facility to accommodate all 5 variants

\section{E. Implementation}

Final Front axle sub assy fixture is installed in the Sub assy line to carry out production. Trail taken for bush pressing assy and clamping of the part. Minor issues were observed like push button position change and clamping location

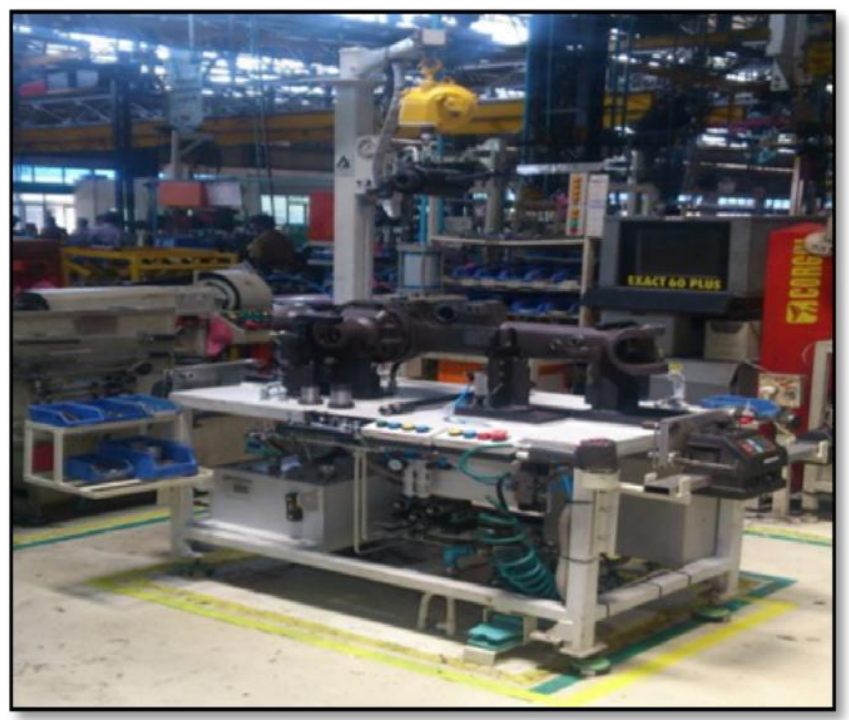

Fig. 17. New sub assy fixture Implemented in assy line

\section{RESULTS AND DISCUSSION}

Takt time reduced to 20.8 to 15.5 min which is within takt time.

After implementation of new sub assy fixture, Productivity increased by 16 Tractors per annum and non-value added activity converted eliminated. Also value added increase to 154 activity from 117 activity

- Through put time $5.5 \mathrm{~min}$ reduced

- Totally 62 mins/day and finally 744 min for annum is saved
- That is approx 16 Tractors production increased / annum

- Totally 24 NVA operation eliminated

- Rework time avoided

Cost involved to manufacture the new facility Rs 2.67 lacs which will be able to recover in 3 months by reducing man power cost

Man power reduction : Rs 96,000

Annual recurring cost saving : Rs 25,000

Maintenance for the machine $\quad$ : Rs 24,500

Total Cost savings $\quad$ : Rs 96,500

Total facility cost

: Rs 2.67 lacs

Return of investment is within 3 months from the date of installation.

\section{CONCLUSION}

The complete design of the $4 \mathrm{WH}$ Bush pressing facility is completed based on the methodology in this phase 1 project. In phase 2 manufacturing of the facility and implementation in the cell 3 assembly line is completed with Bush pressing setup and also Hydraulic clamping system tested and now carried out the front axle assembly at cell 3 without any difficulties.

After successfully implementation of Bush pressing in cell 3 is the same design and concept principles will be used to press the bush at LH \& RH side of front axle housing

\section{REFERENCES}

1. Abdulmaleka, F. and J. Rajgopalb. "Analysing the benefits of lean manufacturing and value stream mapping via simulation: A process sector case study." International Journal of Production Economics 2007

2. Alvarez, R., R. Calvo, et al.. "Redesigning an assembly line through lean manufacturing tools." International Journal of Advanced Manufacturing Technology 2009.

3. Jaiprakash Bhamu, and KuldipSingh Sangwan, Lean manufacturing, Lean production, Emerald Group Publishing Limited (2014) "

4. FarzadBehrouziKuan and YewWong, Lean performance manufacturing system a dynamic innovative approach, Elsevier, 2011.

5. Maria Elena Nenni1, Luca Giustiniano and Luca Pirolo, Improvement of Manufacturing Operations through a Lean Management Approach: A Case Study in the Pharmaceutical Industry, Intech,2014.

6. Perumal puvanasvaram, Hamdan Megar, Lean process management implementation, Journal of industrial engineering and management, 2009

7. Qian Wang and Nick Bennett, Integration of Lean Approaches to Manage a Manual Assembly System, Scientific research publishing, 2014.

8. R.Sundaram,A.N Balaji and R.M. SatheeshKumarc A Review on Lean Manufacturing Implementation Techniques, Elsevier,2014

9. Shawkat Imam Shakil and Mahmud Parvez, Application of Lean Manufacturing in a Sewing Line for Improving Overall Equipment Effectiveness (OEE), Scientific research publishing ,2018.

10. Sharma Neha and Matharou Gurpreet Singh, Kaur Simran3, Gupta Pramod, Lean Manufacturing Tool and Techniques in Process Industry, International Journal of Scientific Research and Reviews(IJSRR)2013.

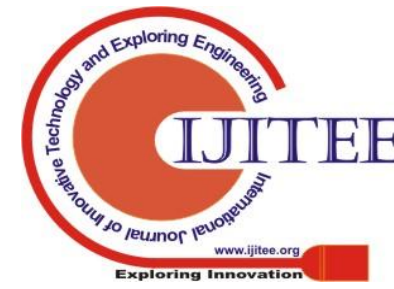

